\title{
ARTYKULY
}

Klio. Czasopismo poświęcone dziejom Polski i powszechnym

PL ISSN 1643-8191, t. 30 (3)/2014, s. 85-99

(c) $($ ) $\Theta$

http://dx.doi.org/10.12775/KLIO.2014.046

AgniesZKa DZiuba

(Lublin)

\section{Gens Claudia i rzymski kult Wielkiej Macierzy - Kybele}

7 wierdzenie, że prof. Maria Jaczynowska poprzez swoje publikacje po1 święcone historii starożytnego Rzymu, w tym nieocenionego podręcznika o tym samym tytule, który w 1988 roku doczekał się siódmego wydania, wykształciła rzesze polskich historyków, jest truizmem. Nie jest nim jednak refleksja, że również dziesiątki filologów klasycznych, z mniejszym lub większym entuzjazmem oddawało się lekturze jej prac, dotyczących nie tylko dziejów nadtybrzańskiego imperium, ale także religii świata rzymskiego. Tej ostatniej problematyce została poświęcona książka wydana w Warszawie w 1987 roku, nakładem Państwowego Wydawnictwa Naukowego. Ta pozycja bibliograficzna jest niezwykle pomocna w pracy filologa, który zazwyczaj patrzy na świat wierzeń Rzymian przez pryzmat tak popularnych wciąż w naszym gronie mitologii ${ }^{1}$. Rzeczowa, logiczna i nie-

1 Wystarczy wspomnieć chociażby ostatnie publikacje różnych pokoleń filologów z tego zakresu: Z. Kubiak, Mitologia Greków i Rzymian, Warszawa 1997; L. Stankiewicz, Ilustrowany stownik mitologii greckiej i rzymskiej, Wrocław, Warszawa 2008; K. Marciniak, Mitologia grecka i rzymska, Warszawa 2010. 
zwykle kompetentna narracja wybitnej znawczyni antyku w przejrzysty, a zarazem naukowy sposób przybliża czytelnikowi trudny problem i pozwala zbudować każdemu filologowi solidny warsztat badawczy. Ułatwia tym samym typowo filologiczną pracę. Nie sposób bowiem analizować tekstów bez ich kulturowego kontekstu, który w świecie rzymskim sprowadza się przede wszystkim do tradycji i religii. Niniejszy artykuł jest wyrazem hołdu dla wybitnej Uczonej, a inspiracją do jego napisania były informacje zawarte w tekście Religii świata rzymskiego na temat kultu Wielkiej Macierzy bogów - Kybele. Prof. Jaczynowska kilkakrotnie pisze w swojej pracyo bogini z Pesinuntu. Na s. 62-64 przedstawia okoliczności sprowadzenia do Rzymu tego egzotycznego kultu, na s. 135-136 wspomina o popularności Kybele w Ostii w początkach pryncypatu, a s. 197-199 są poświęcone kultowi w okresie cesarstwa.

Celem artykułu nie jest żadną miarą polemika z ustaleniami Profesor, a jedynie drobne uzupełnienie Jej wywodu o aspekt badań filologicznych, które ze zrozumiałych względów w Jej książce znaleźć się nie mogły. Autorka zamierza bowiem prześledzić, w jakich okolicznościach pojawiały się w źródłach literackich wzmianki na temat rzymskiego kultu Kybele w kontekście dziejów gens Claudia. Interesujące będzie także prześledzenie ewolucji legendy o Klaudii Kwincie i jej roli w sprowadzeniu wizerunku bogini do Rzymu.

Ten dość egzotyczny, bo w niektórych swoich przejawach niezgodny z normami rzymskiej obyczajowości, kult² został sprowadzony do Miasta „decyzją” Ksiąg Sybillińskich. W 205 roku p.n.e., a więc wciąż jeszcze w czasie krwawej wojny z Hannibalem, decemwirowie szukający pomocy w rozwiązaniu długoletniego konfliktu z Kartaginą, przeczytali w księgach, że jedynie sprowadzenie Kybele umożliwi wypędzenie Hannibala z Italii ${ }^{3}$. Jak pisze prof. Jaczynowska: „orzeczenie [to] nawiązywało do tradycji trojańsko-rzymskich, bowiem Ida była górą Troi” ${ }^{4}$. Było religijnym umocnie-

${ }^{2} \mathrm{Na}$ temat samego kultu zob.: H. Kowalski, Ludi Megalenses - obrzędy, widowiska, teatr, [w:] Obrzęd, teatr, ceremoniat w dawnych kulturach, red. J. Olko, Warszawa 2008, s. $107-118$.

${ }^{3}$ Livius, XXIX,10.

${ }^{4}$ M. Jaczynowska, Religie świata rzymskiego, Warszawa 1987, s. 62. 
niem sojuszu zawartego z Attalosem I, królem Pegamonu5. Testimonia literackie od początku wiązały sprowadzenie kultu z jednym z gentes maiores patrycjatu, a mianowicie z Klaudiuszami. Prof. Jaczynowska pisze, że święty kamień z Pessinuntu, symbolizujący samą boginię, przywieziony okrętem z Azji do Rzymu, został uroczyście przyjęty przez „najlepszego obywatela i najlepszą obywatelkę", czyli Publiusza Scypiona i Klaudię Kwintę . Jak słusznie zauważyła Badaczka, taki wybór delegatów był wyrazem zbliżenia dwóch, dotychczas rywalizujących ze sobą factiones przeciw trzeciejFabiuszom. E. Fantham, w komentarzu do Fasti Owidiusza, sugeruje, że Klaudię Kwintę wybrano, gdyż jej kuzyn, Gajusz Klaudiusz Nero, był w 204 roku p.n.e. cenzorem ${ }^{7}$. O okolicznościach powitania kamienia prof. Jaczynowska wspomina ponadto w zdaniu: „Legenda opromieniła jeszcze te uroczystości, a zwłaszcza osobę Klaudii Kwinty, która miała w cudowny sposób doprowadzić okręt do brzegu"».

W zachowanych źródłach literackich chronologicznie najstarsza wzmianka o roli Klaudii Kwinty w sprowadzeniu Kybele do Rzymu znajduje się w mowie Marka Tuliusza Cycerona. Wybitny mówca, przemawiający jako ostatni, czyli szósty orator w procesie Marka Celiusza Rufusa, zaatakował swoją przemową Klodię Metellę, świadka oskarżenia bronionego przez siebie młodego ekwity. Co ciekawe, proces toczył się w czasie Ludi Megalenses przypadających na początek kwietnia świąt ku czci matki bogów. W 56 roku p.n.e., kiedy doszło do procesu, śmiertelny wróg Arpinaty i brat Klodii Publiusz Klodiusz jako edyl przewodniczył inscenizacjom teatralnym, które od 196 roku towarzyszyły tym świętom9. W tym czasie, najprawdopodobniej 4 kwietnia, Cyceron, wygłaszając mowę

\section{${ }^{5}$ Ibidem.}

${ }^{6}$ M. Jaczynowska, op.cit., s. 63.

${ }^{7}$ Ovid, Fasti Book IV, ed. E. Fantham, Cambridge 1998, s. 153-154.

${ }^{8}$ M. Jaczynowska, op.cit., s. 63.

9 W czasie Ludi Megalenses wystawiano komedie. W trakcie innych świąt Rzymianie oglądali przedstawienia tragedii, wśród których znajdowały się też utwory o tematyce zaczerpniętej z rzymskiej historii (fabulae togatae). T. P. Wiseman powołując się na krótką wzmiankę u Owidiusza (sed et scena testificata loquar, Fasti, IV, 326) uważa, że istniała tragedia poświęcona Klaudii Kwincie. Zob.: T. P. Wiseman, Satyr in Rome?, [w:] idem, Historiography and Imagination: Eight Essays on Roman Culture, Exeter 1994, s. 68-85. 
obrończą, bezpardonowo zaatakował Klodię Metellę, zarzucając kobiecie wszelkie występki przeciw moralności, z insynuacją otrucia męża włącznie. Powtarzające się zarzuty wybitny mówca urozmaicał różnorodną, niekiedy bardzo wyszukaną formą ich przedstawiania. W jednej z nich: patetycznej prozopopei przywołał postać Appiusza Klaudiusza Cekusa, który jak przystało na protoplastę rodu, karcił kobietę, odwołując się do przykładów cnót przedstawicielek gens Claudia z przeszłości. Jako pierwsza została przywołana wnuczka cenzora:

Nonne te, si nostrae imagines viriles non commovebant, ne progenies quidem mea, Q. illa Claudia, aemulam domesticae laudis in gloria muliebri esse admonebat... $(14,34)^{10}$.

Skoro nie wzruszają cię męskie wizerunki naszego rodu, to może zdoła nakłonić cię do rywalizacji na polu sławy w chwale kobiecej moja wnuczka, owa słynna Klaudia Kwinta ${ }^{11}$.

O ile ożywiona talentem mówcy postać starca nie uściśla, czego miałaby dotyczyć sława Klaudii, o tyle w mowie De haruspicum responso, wygłoszonej prawdopodobnie już w maju 56 roku p.n.e., Cyceron dobitnie podkreśla wyróżnianie się Klaudii Kwinty na polu obyczajności i poszanowania dawnej religijności. Postać kobiety została przywołana w kontekście ataku ad personam na Klodiusza. Arpinata jako znakomity stylista przeprowadza krytykę przeciwnika za pomocą synkrisis, a więc przeciwstawnego porównania historycznej postaci z Klodią, siostrą trybuna. W typowy dla siebie sposób nie uderza bezpośrednio w antagonistę, co nie umniejsza wcale efektu napaści. Arpinata pisze:

...femina autem quae matronarum castissima putabatur, Quinta Claudia, cuius priscam illam severitatem [sacrificii] mirifice tua soror existimatur imitata $(13,27)^{12}$.

${ }^{10}$ Cicero, Pro M. Caelio oratio, ed. R. G. Austin, Oxford $1960^{3}$.

${ }^{11}$ O ile nie zaznaczono inaczej, wszystkie tłumaczenia pochodzą od autorki.

${ }^{12}$ M. Tulli Ciceronis scripta quae manserunt omnia, fasc. 21. ed. T. Maslowski, Leipzig 1981. 
Kobieta, którą uważano za najcnotliwszą wśród matron, Klaudia Kwinta, a której ową dawną surowość [ofiary] w przedziwny sposób twoja siostra wydaje się naśladować.

W Cycerońskich zdaniach został przywołany obraz Klaudii Kwinty jako exemplum idealnej matrony rzymskiej. Kobieta wyraźnie pojawia się w tekście obu mów w roli antytetycznej postaci wobec niemoralnej Klodii Metelli. Wnuczka Cekusa zdobyła sławę (gloria muliebris) na właściwym Rzymiance polu aktywności (domestica laus). Cyceron podkreśla najważniejsze dla kobiety rzymskiej cnoty (castitas, pudicitia), które realizowała Klaudia Kwinta ${ }^{13}$, pisząc, że była najcnotliwszą spośród matron, a także podkreślając jej wierność wobec surowych zasad przodków. Należy ponadto zaznaczyć, że oba Cycerońskie zdania mają kunsztowną konstrukcję retorycznych figur, pierwsze emotywnej prozopopei, drugie sugestywnej, obrazowej synkrisis.

Kolejnym autorem, który wspomina o interesującym nas wydarzeniu jest Tytus Liwiusz. Historyk dość lakonicznie i bez zbytniej dramatyzacji opowiada, że kobiety, zgromadzone nad Tybrem, przekazywały sobie z rąk do rąk artefakt bogini (eae per manus succedentes deinde aliae aliis - AUC $29,14,11-13)^{14}$. Z grona rzymskich matron wymienia tylko jedną z nich, a mianowicie Klaudię Kwintę, której obecność w tak zacnym towarzystwie miała oczyścić kobietę z „wątpliwej opinii” na temat jej obyczajności:

...inter quas unius Claudiae Quintae insigne est nomen accepere; cui dubia, uttraditur, antea fama clariorem ad posteros tam religioso ministerio pudicitiam fecit (AUC, 29, 14, 11-13.).

między którymi wymienia się imię jednej tylko Klaudii Kwinty. Miała ona do owego czasu, jak podają, wątpliwą opinię, ale, ta religijna służba sprawiła, że jej czystość obyczajów zyskała u potomnych nieprzeciętną sławę ${ }^{15}$.

${ }^{13} \mathrm{Ph}$. Culham, Women in the Roman Republic, [w:] The Cambridge Companion to the Roman Republic, red. H. I. Flower, Cambridge 2006, s. 139.

${ }^{14}$ Livius, XXVII-XXX.

15 Tytus Liwiusz, Dzieje Rzymu od zatożenia miasta. Ks. XXVIII-XXXIV, przeł. i oprac. M. Brożek, Wrocław-Warszawa 1976, s. 93. 
Liwiusz jest tym samym pierwszym autorem, który wspomina o „dowodzie niewinności”, jaki musiała złożyć patrycjuszka, by oczyścić się z ciążących na niej zarzutów. Nie tłumaczy jednak, czego owa niesława miała dotyczyć. Arpinata, który, mimo konfliktu z Publiuszem Klodiuszem i wyraźnej predylekcji do stosowania inwektywy, nie wspomina o jakiejkolwiek plamie na opinii Klaudii, chyba, że określenie castissima matronarum można rozumieć jako efekt udanego dowodu niewinności. Wydaje się jednak, że taka interpretacja jest mało realistyczna. Bardziej prawdopodobne jest, że w czasach Cycerona nie istniała jeszcze legenda o Klaudii Kwincie, która musiała udowadniać swoją cnotliwość za pomocą cudu Kybele ${ }^{16}$. Tym bardziej, że była ona piątą z córek Klaudiusza, a więc gdyby istniał choćby cień podejrzeń co do czystości jej obyczajów, wskazano by pewnie na inną z sióstr. Chyba, że była jedyną żyjącą przedstawicielką rodu. Można więc przypuszczać, że republika nie znała jeszcze legendy o Klaudii Kwincie. Być może opowieść o konieczności udowodnienia przez Klaudię swojej niewinności powstała na płaszczyźnie tworzącej się w pierwszym wieku negatywnej opinii o gens Claudia, do powstania której bez wątpienia przyczyniło się zachowanie kontestującego mores maiorum potomstwa Appiusza Klaudiusza, konsula 79 roku p.n.e. ${ }^{17}$.

Najobszerniej i zarazem najpiękniej pod względem literackim wprowadzenie Kybele do Rzymu opisał poeta Owidiusz. W czwartej księdze Fasti nie tylko przypomniał Rzymianom pochodzenie bogini, początki jej kultu oraz postać miłego sercu Kybele Attisa, ale także drogę wiozącego ją okrętu, który niespodziewanie zatrzymał swoją podróż w Ostii i mimo podejmowanych prób ciągnięcia statku linami przez wiele osób, ani drgnął. Cudu dokonała Klaudia Kwinta:

16 E. Winsor Leach uważa, że Cyceron nie wspomina o „dowodzie cnoty”, bo albo jeszcze legenda się nie rozwinęła, albo świadomie ją przemilczał, gdyż miał inny cel. Zob.: E. Winsor Leach, Claudia Quinta (Pro Caelio 34) and an altar to Magna Mater, Dictynna 2007, nr 4, s. 3 [http://dictynna.revues.org.157].

${ }^{17}$ H. Kowalski także uważa, że legenda o Klaudii kształtuje się od połowy I wieku. Zob.: H. Kowalski, op.cit., s. 112. 
Claudia Quinta genus Clauso referebat ab alto, nec facies inpar nobilitate fuit,

Casta quidem, sed non et credita; (w. 305-307) ${ }^{18}$.

Klaudia Kwinta co ród swój wiodła od Klaudiusza, starca, z twarzy szlachetna równie tak jak z rodu, cnotliwa była, chociaż nie chciano jej wierzyć19 ${ }^{19}$.

Ze słów poety wynika, że zarzuty stawiane Klaudii były związane raczej z jej brakiem szacunku dla tradycji, niż z występkami natury obyczajowej:

...rumor iniquos

laeserat et falsi criminis acta rea est;

cultus et ornatis varie prodisse capillis

obfuit ad rigidos promptaque lingua senes (w. 307-310).

Podniósł się nieprzyjazny szmer, wtedy została oskarżona fałszywie: że dba o fryzurę, gdy idzie na przechadzkę, że nie ma szacunku wobec starców czcigodnych ${ }^{20}$.

Zarzuty stawiane patrycjuszce wpisują się w literacki obraz kobiety, utrwalanej przez mizoginiczną poezję Plauta i Lukrecjusza, którzy zarzucali Rzymiankom zbytnią dbałość o wygląd zewnętrzny i trwonienie na ten cel majątku ${ }^{21}$. Natomiast drugi człon „zarzutu” nasuwa skojarzenia ze słynnym wierszem o pocałunkach Gajusza Waleriusza Katullusa, w którym poeta każe kobiecie nie liczyć się z opinią surowych starców (rumoresque senum severiorum... - Carm. 5, w. 2). Wielowiekowa tradycja literacka identyfiku-

${ }^{18} \mathrm{P}$. Ovidius Naso. vol. III, fasc. 2 Fastorum libri VI fragmenta, ed. R. Ehwald,F. W. Levy, Lipsiae 1924.

${ }^{19}$ Owidiusz, Fasti. Kalendarz poetycki, przeł. i oprac. E. Wesołowska, WrocławWarszawa-Kraków 2008, s. 161.

${ }^{20}$ Ibidem.

${ }^{21}$ A. Dziuba, Nec Hercules contra plures, Literacki aspekt Liwiańskiej debaty nad zniesieniem Lex Oppia (AUC 34, 1-8), „Roczniki Humanistyczne” 2010/2011, t. 58-59, z. 3 , s. 74 . 
jąca Lesbię, adresatkę erotyków Katulla, z Klodią Metellą, pozwala wysnuć wniosek, że erudyta Owidiusz przywołuje poetyckie zarzuty, jedne zaczerpnięte z topiki inwektywy, wykorzystywanej przez archaicznych poetów, drugie zapożyczone z twórczości poety, działającego pokolenie wcześniej i blisko związanego z gens Claudia. Być może więc Owidiusz nie dysponował szczegółową wiedzą na temat przewinień Klaudii, bo takich informacji legenda nie podawała. Kolejne słowa eposu przynoszą obraz znękanej kobiety, która prosi w modlitwie Kybele o pomoc w udowodnieniu niewinności. Bogini wysłuchała błagań pomówionej i matrona pociągnęła za sznur, a okręt ruszył. R. J. Littlewood uważa, że Owidiusz, opisując wzruszający portret patrycjuszki, chciał pozyskać przychylność Liwii poprzez złożenie hołdu jej antenatce ${ }^{22}$. Natomiast J. Gérard sugeruje, że legenda o Klaudii była elementem propagandy rodu Klaudiuszy ${ }^{23}$. W okresie cesarstwa do tego epizodu nawiązują jeszcze między innymi Pliniusz Starszy, Waleriusz Maximus i poeta Stacjusz. Natomiast nic o wyróżnionej kobiecie nie wspomina żyjący w II i III w. n.e. Kasjusz Dion, który pisze, że Publiusz Scypion, syn Gnejusza, sprowadził posąg do miasta w otoczeniu najwybitniejszych kobiet $^{24}$. Krótka wzmianka o Klaudii, która sprowadziła do Rzymu matkę bogów w ramach usankcjonowanego religijnie dowodu swej niewinności, znajduje się w Historii naturalnej Pliniusza Starszego ${ }^{25}$, natomiast Stacjusz czyni z kobiety w swoich Sylwach westalkę ${ }^{26}$. W tym miejscu napotykamy kolejną zagadkę związaną z Klaudią Kwintą, gdyż nie wiadomo, kiedy i dlaczego matrona przekształciła się w kapłankę Westy. Stało się tak być może dlatego, że w okresie cesarstwa nie przywiązywano już takiej wagi do nieposzlakowanej opinii mężatki, a jedyną grupą kobiet, które były postrzegane

${ }^{22}$ R. J. Littlewood, Poetic Artistry and Dynastic Politics: Ovid at the Ludi Megalensis (Fasti 4,179-372), „Classical Quarterly” 1981, t. 22, s. 381-395.

${ }^{23}$ J. Gérard, Légende et politique autour de la mère des dieux, „Revue des Études Latines" 1980, t. 58, s. 161-162.

${ }^{24}$ Kasjusz Dion Kokcejanus, 17, 61.

25 Pliniusz pisze: religionis experimento Claudia inducta Romam deum matre. C. Plini Secundi Naturalis Historiae libri XXXVII, ed. C. Mayhoff, vol. II, libri VII-XV, Lipsiae 1909 .

${ }^{26}$ U Stacjusza czytamy: non Claudia talis respexit populos mota iam virgo carina (1, 2, 245. P. Papini Stati Silvae, rec. A. Marastoni, Leipzig 1970). 
przez pryzmat swojej czystości (rozumianej jako dziewictwo) były westalki. Idąc tym tropem, można przypuszczać, że czytelnicy Stacjusza uważali, iż interwencja bogini nie tylko oczyściła kobietę z zarzutu niemoralności, ale tym samym uratowała jej życie. Prawdopodobnie Stacjusz nie jest autorem takiego wizerunku Klaudii, lecz jedynie wyrazicielem współczesnych sobie poglądów. Świadczy o tym scena wyryta na ołtarzu wotywnym pochodzącym z I lub II wieku n.e., na którym został przedstawiony okręt bogini (z jej wyobrażeniem pod postacią siedzącej kobiety) i drugiej niewiasty (przedstawionej w stroju westalki), która ciągnie statek ${ }^{27}$. Podpis pod wyobrażeniem brzmi:

\author{
Matri deum et navi Salviae \\ Salviae voto sucepto \\ Claudia Syntyche \\ $d($ onum $) d(\text { edit })^{28}$. \\ Matce bogów i okrętu Salwia. \\ Jako spełnienie ślubów za Salwię, \\ Klaudia Syntyche \\ złożyła ten dar.
}

Jak słusznie pisze Marilyn B. Skinner, wyzwolenica o imieniu Syntiche, należąca wcześniej do pana z rodu Klaudiuszy, potwierdza więzi łączące ród z kultem Magna Mater ${ }^{29}$. Zdecydowana większość badaczy pozostaje jednak przy republikańskiej wizji Klaudii jako matrony. Do nielicznej grupy zwolenników cesarskiej koncepcji należy włoski uczony Luca Fezzi, dla którego patrycjuszka jest westalką ${ }^{30}$. Warta uwagi jest także wzmianka w dziele Waleriusza Maximusa na temat posągu Klaudii Kwinty, jaki prawdopodobnie znajdował się w westybulu świątyni Kybele i miał cudowne właściwości. Mimo dwukrotnego pożaru świątyni (w 111 roku p.n.e. i 3 roku n.e.),

\footnotetext{
27 Ołtarz znajduje się w Muzeum Kapitolińskim w Rzymie.

28 CIL VI 492.

${ }^{29}$ M. B. Skinner, Clodia Metelli. The Tribune's Sister, Oxford 2011, s. 31.

${ }^{30}$ L. Fezzi, Il tribuno Clodio, Bari 2008, s. 14.
} 
statua pozostała nienaruszona (... in sua Basi flammis intacta stetit- I,8,11) ${ }^{31}$. Wzmiankę tę potwierdza także Tacyt w Annales, który dodaje jako uzasadnienie cudu, że Klaudiusze byli świętymi i miłymi bóstwom (sanctos acceptosque numinibus Claudios - IV, 64, 3-4). W ten sposób obaj autorzy multiplikują cudowne zdarzenia będące udziałem patrycjuszki, która nie tylko poruszyła okręt, ale także cech świętości nabrało jej wyobrażenie, stojące w świątyni Matki Bogów. Informacja Tacyta i Waleriusza potwierdza, że więzi łączące gens Claudia z kultem Kybele, były łatwo dostrzegalne przede wszystkim w legendzie o wnuczce Cekusa i sprowadzeniu posągu do Rzymu. Jak wyżej wspomniano, legenda ewoluowała aż do czasów cesarstwa. Ponadto posąg kobiety stale towarzyszył wyobrażeniu bogini. O tym, że kult Kybele był bliski rodowi, może świadczyć wiersz wspomnianego wyżej Gajusza Waleriusza Katullusa, poety z Werony, należącego do kręgu przyjaciół skandalizującego rodzeństwa Publiusza Klodiusza i Klodii Metelli. W zbiorze Catulli Veronensis Liber znalazł się utwór pisany rzadkim w poezji łacińskiej metrum, a mianowicie galijambami. Należący do grupy dłuższych utworów, opatrzony numerem 63, a zaczynający się od słów: Super alta vectus Attis celere rate maria...(„Attis, po szerokich falach morza płynąc...”) ${ }^{32}$, utwór jest ciekawą interpretacją rozterek duchowych młodzieńca po akcie samokastracji. Jednakże nie wiersz jest w tym miejscu ważny, lecz sam fakt jego powstania. Według najbardziej rozpowszechnionej wersji identyfikacji bohaterki erotyków Katulla - Lesbii z Klodią Metellą, poeta z Werony miał być kochankiem, ostatecznie porzuconym, pięknej patrycjuszki. Swobodnie interpretując informacje zaczerpnięte zarówno od Cycerona (o ucztach urządzanych w domu Klodii dla męskiej młodzieży), jak i z pieśni neoteryka (o konkursach poetyckich urządzanych w czasie uczt z przyjaciółmi), można wyobrazić sobie, że utwór ten, oryginalny w zbiorze 116 carmina Weroneńczyka, powstał jako swoisty dar/hołd dla przedstawicielki rodu, któremu szczególnie bliski był egzotyczny kult ${ }^{33}$.

31 Valerii Maximi, Factorum et dictorum memorabilium libri novem [...], rec. et emend. C. Kempfius, Berolini 1854.

${ }^{32}$ Katullus, Poezje wszystkie, przekł.G. Franczak, A. Klęczar, wstęp A. Klęczar, Kraków 2013, s. 384-385.

33 O tym, że w kręgu przyjaciół poety interesowano się Kybele świadczy twórczość nieznanego skądinąd Cecyliusza, o którym Katullus pisze w pieśni 35, że zaczyna tworzyć poemat o idajskiej bogini. 
Gens Claudia pojawia się w kontekście kultu Kybele nie tylko przez skojarzenie z Klaudią Kwintą. Cyceron w mowach Pro Sestio (56) i De domo sua $(50,129)$ atakował Publiusza Klodiusza w związku ze sprzedażą funkcji kapłana Magna Mater niegodnemu, zdaniem Arpinaty, tego stanowiska Brogitarusowi w 58 roku, a więc za swojego trybunatu ${ }^{34}$. Natomiast w mowie De haruspicum responso Cyceron zarzucił Publiuszowi spowodowanie zamieszek w czasie obchodów Ludi Megalenses:

Vis enim innumerabilis incitata ex omnibus vicis collecta servorum ab hoc aedile ${ }^{35}$ religioso repente e fornicibus ostiisque omnibus in scaenam signo dato inmissa inrupit $(11,22)^{36}$.

Albowiem niepoliczona liczba podburzonych niewolników, zebranych po wsiach przez tego religijnego edyla, wypadła na dany sygnał, nagle wypuszczona, przez wszystkie sklepione bramy na scenę.

Z Cycerońskich napomknień trudno jest wywnioskować, na czym rzeczywiście polegało zakłócenie uroczystości. Mówca wspomina jedynie, ale za to konsekwentnie, o wprowadzeniu przez Publiusza do teatru zor-

${ }^{34}$ Takie przedstawienie faktów oraz interpretacja Klodiuszowego prawa de rege Deiotaro et Brogitharo przez Cycerona pozwala dostrzec absolutny brak obiektywizmu i świadome zafałszowanie przekazu przez mówcę. W kontekście rzymskiego oratorstwa nie było to niczym niestosownym, a często wręcz oczekiwanym przez słuchaczy, gdyż personalne ataki wzbudzały sensację, bawiły i skupiały uwagę licznie przybyłej na proces gawiedzi. Historycy starożytności, w tym nieoceniony biograf Klodiusza W. J. Tatum, autor książki The Patrician Tribune. Publius Clodius Pulcher, Chapel Hill-London 1999, obiektywnie zinterpretował fakt konfliktu między Pompejuszem, który uhonorował Dejotara, tetrarchę zachodniej Galacji, stanowiskiem najwyższego kapłana Kybele w Pessynuncie, a Klodiuszem, który przeniósł ten tytuł na Brogitara, zięcia Dejotara i władcę Trocmi w zachodniej Galacji. Historyk obalił Cycerońskie oskarżenie o partykularny interes rodu, polegający na przyjęciu korzyści finansowych i wskazał na aspekt polityki międzynarodowej. Klodiusz poprzez lex Clodia de rege Deiotaro et Brogitaro dążył przede wszystkim do umniejszenia znaczenia Pompejusza w polityce Rzymu i na arenie międzynarodowej. Temu celowi służyło między innymi odwołanie przynajmniej części jego ustaleń dotyczących Wschodu. Zob.: W. J. Tatum, op.cit., s. 169.

${ }^{35}$ Jak wyżej wspomniano, Publiusz Klodiusz był w 56 r. edylem plebejskim, a więc urzędnikiem odpowiedzialnym za organizację i prawidłowy przebieg święta.

${ }^{36}$ Zob. także: 11,$23 ; 12,24$. 
ganizowanej bandy niewolników, która na znak dany przez edyla przerwała przedstawienie. J. O. Lenaghan, autor komentarza do mowy ustala incydent na $8 \mathrm{kwietnia}^{37}$. Tu także mamy do czynienia z retoryczną wizją zdarzenia. H. Kowalski słusznie zauważa, że historycy powszechnie odrzucają Cycerońską interpretację o świętokradztwie trybuna dokonanym poprzez naruszenie religijnego charakteru igrzysk ${ }^{38}$. Polski badacz $\mathrm{w}$ erudycyjnym artykule przytacza kilka propozycji interpretacyjnych zachowania Klodiusza. Najbardziej wiarygodna dotyczy kontynuacji sporu między dawnym patrycjuszem, realizującym w rzeczywistości interesy polityczne nieobecnego w Rzymie Cezara, a Pompejuszem. J. W. Tatum zauważa, że zamieszki w czasie ludi Megelenses stanowiły dalszy ciąg niepokojów społecznych, jakie odnotowano w Rzymie w początkach roku 56. Były one związane ze złym nadzorowaniem rozdawnictwa zboża przez Pompejusza ${ }^{39}$. Należy zgodzić się z historykiem, że Klodiusz jako edyl przewodniczący przedstawieniom teatralnym skorzystał ze znakomitej okazji do zamanifestowania „niezadowolenia ludu” z polityki rozdawnictwa zboża triumwira. Nadawanie temu wydarzeniu cech przestępstwa wobec religii to typowa przesada retoryczna, stale obecna $\mathrm{w}$ mowach Arpinaty. Do loci communes Cycerońskiej inwektywy ad personam należy podkreślanie kontaktów atakowanego z niewolnikami lub prostytutkami. W tak prosty sposób mówca godzi w dignitas Klodiusza. Podobny zabieg zastosował orator wobec Katyliny, Pizona, Klodii Metelli, a w przyszłości takich samych argumentów użyje wobec Marka Antoniusza, za co zapłaci życiem. Nie należy więc dosłownie odczytywać zarzutów Cycerona, który oburzony faktem manifestacji plebejskiej, chciał widzieć w zgromadzonym ludzie jedynie niewolników, a w Klodiuszu bluźniercę.

Podsumowując powyższe rozważania, należy zauważyć szczególną obecność gens Claudia w literackiej deskrypcji okoliczności sprowadze-

37 J. O. Lenaghan, A Commentary on Cicero's Oration "de Haruspicum responso", Hague 1969, s. 22-31. Natomiast M. R. Salzman przesuwa tę datę na 10 kwietnia. M. R. Salzman, Cicero, The Megalenses and the Defense of Caelius, „The American Journal of Philology" 1982, t. 103, s. 299-304, s. 303-304.

${ }^{38}$ H. Kowalski, op.cit., s. 113-114.

39 J. W. Tatum, op.cit., s. 111. 
nia kultu Kybele do Rzymu. Jednocześnie zachowane wzmianki o Klaudii Kwincie czy o samej bogini w tekstach późniejszych autorów, szczególnie w mowach Cycerona i eposie Owidiusza, świadczą o stałych odniesieniach przedstawicieli rodu do wschodniej bogini. Szczególnie widoczne jest to w okresie działalności Publiusza Klodiusza, kiedy to, być może w kontekście ataku na Klodię Metellę, mogła zrodzić się widoczna w tekstach z okresu cesarstwa legenda o pomówieniu wnuczki Appiusza Klaudiusza Cekusa o brak szacunku dla tradycji, który w przypadku kobiet przeradzał się w groźny, bo dwuznaczny, zarzut niemoralności. Być może pewne poczucie odpowiedzialności Klaudiuszy za kult przejawiało się nie tylko w pielęgnowaniu opowieści o „cudzie” z poruszeniem statku przez cnotliwą antenatkę, ale także w opiece nad świątynią czy żebrzącymi kapłanami. Dysponując przede wszystkim źródłami literackimi, nie sposób obiektywnie ocenić zaangażowania gens Claudia w egzotyczny kult. O ile wiadomo, Klaudiusze prywatnie czcili boga Saturna ${ }^{40}$, a obrzędy ku jego czci sprawowali w nieco ekstrawagancki sposób, narażając się przy tym na krytykę konserwatywnego Katona Cenzora ${ }^{41}$, o tyle nie wiemy, czy w rzeczywistości przedstawiciele rodu czuli się w jakiś sposób odpowiedzialni za funkcjonowanie kultu w Rzymie. Obraz, jaki wyłania się z tekstów literackich, pozwala jedynie opisać mniej lub bardziej świadomą obecność Klaudiuszy w epizodach związanych z przebiegiem świąt ku czci Matki bogów. Bez wątpienia jednak to imię Klaudiuszy najczęściej kojarzone jest w tekstach z opowieścią o obecności bogini z Pesinuntu w Rzymie, co oprócz legendy o Klaudii Kwincie, jest w pozostałych przypadkach ewidentnie zasługą Marka Tuliusza Cycerona i po mistrzowsku wykorzystanego przez znakomitego retora zbiegu okoliczności, jakim były kwietniowe Ludi Megalenses 56 roku p.n.e. i proces Celiusza oraz konflikt Publiusza Klodiusza z Pompejuszem. Być może jednak dowodu na powiązanie gens Claudia z kultem Kybele w Rzymie dostarcza prof. Maria Jaczynowska, która w interesującej nas pracy pisze, że to cesarz, wywodzący się z tego

${ }^{40}$ W Fasti Owidiusza czytamy, że ród sprowadził do Rzymu kult Bona Dea (Fasti 5, 155 i nn.).

41 S. Szczygieł, Marek Porcjusz Katon. Rzymski tradycjonalista czy polityk realista, Warszawa 2011, s. 175. 
rodu, Klaudiusz „pozwolił na publiczne formy kultu Wielkiej Macierzy [...] i odtąd mógł się on w pełni rozwinąć"

\title{
Gens Claudia and the Roman cult of Magna Mater (Cybele)
}

\author{
(SUMMARY)
}

Eminent historian of ancient Rome, Professor Maria Jaczynowska, was a teacher of many generations of not only historians, but also classical philologists. This article is written by classical philologist who is grateful for Professor's research effort. The inspiration is recognized by the outstanding Scientist Jaczynowska topic of Claudii in the Roman cult of Magna Mater (Cybele). It has been described so far in only one Polish monograph "Religions of the Roman world" published in Warsaw in 1987. The purpose of this article is to make a fine complement to observations done by Professor Jaczynowska in aspect of philological research, which for obvious reasons could not be included in Her book. Analysis of extant literary sources in the context of references to the role of representatives of the family Claudii in bringing Cybele to Rome in 204, and Ludi Megalenses of $56 \mathrm{BC}$, brings us to interesting conclusions. The texts of Cicero, Livy, Ovid, Valerius Maximus, Tacitus, Statius and a minor mention in other ancient writers works, let us draw a conclusion about undeniable ties between gens Claudia and the cult of the goddess of Pesinunt. The reason is that the matron, who was delegated to welcome the Magna Mater to Rome was Claudia Quinta, the grandchild of censor Appius Claudius Caecus. Undoubtedly, the historical fact evolved since the days of the Republic till the second century of Empire into the literary legend of the "miracle of the goddess" who gave "proof of innocence" to the dishonored patrician. Another "miracle" is associated with a standing in the temple of the goddess statue of matron. Interesting is also the evolution of Claudia who was described in Republican texts as a matron, and in imperial times as a vestal virgin. The Legend of Claudia Quintais the strongest proof that the gens Claudia was described in the sources as closely associated with the cult of Cybele. However, references in the works of Cicero regarding the sale

${ }^{42}$ M. Jaczynowska, op.cit., s. 197. 
of a priest position to Brogitar by Publius Clodius and the riots called by him during Ludi Megalenses in $56 \mathrm{BC}$ is, as historians say, the element of rhetorical invective on the tribune hated by Cicero.

Agnieszka Dziuba

Katedra Filologii Łacińskiej, Katolicki Uniwersytet Lubelski Jana Pawła II dziubak@kul.lublin.pl 